\title{
Vitamin D Deficiency and Insufficiency According to the Current Criteria for Children: Vitamin D Status of Elementary School Children in Turkey
}

\author{
(D) F. Sinem Hocaoğlu-Emre ${ }^{1}$, (D) Devrim Sarıbal2, (D) Osman Oğuz ${ }^{3}$ \\ ${ }^{1}$ Beykent University School of Health Sciences, Department of Nutrition and Dietetics, istanbul, Turkey \\ 2istanbul University Cerrahpaşa, Cerrahpaşa Faculty of Medicine, Department of Biophysics, Istanbul, Turkey \\ 3istanbul Training and Research Hospital, Department of Clinical Chemistry, Istanbul, Turkey
}

What is already known on this topic?

Vitamin D deficiency and insufficiency is a widely observed condition among children, especially in winter and post-winter periods.

What this study adds?

Our study determined the frequency of vitamin D deficiency and insufficiency in a large group of children of elementary school age, based on seasonality. Particularly, this is the first study, determining serum $25(\mathrm{OH}) \mathrm{D}$ levels in this age group, subclassified into different seasons.

\begin{abstract}
Objective: This study aimed to determine the ratio of seasonal vitamin D deficiency and insufficiency in elementary school children aged between 6-9 years old, living in one of the largest metropols of Europe, İstanbul.

Methods: Serum 25(OH)D levels of 640 children aged 6-9 years old were scanned retrospectively from the hospital information system records between September 2017-August 2018 period. Vitamin D deficiency was defined as a serum 25(OH)D level less than $12 \mathrm{ng} / \mathrm{mL}$ (30 nmol/L) and insufficiency as levels between 12 and $20 \mathrm{ng} / \mathrm{mL}(30-50 \mathrm{nmol} / \mathrm{L})$.

Results: Serum 25(OH)D levels ranged from 3.90 to $64.60 \mathrm{ng} / \mathrm{mL}$, the median value was $25.95 \mathrm{ng} / \mathrm{mL}$ for all subjects. Of all the primary school children, 485 (75.78\%) had adequate levels of 25(OH)D. Vitamin D deficiency was observed in 36 of children (5.62\%), whereas insufficient levels of 25(OH)D were found in 119 children $(18.60 \%)$. The ratio of vitamin D insufficiency and deficiency together was highest in spring $(31.87 \%)$ and lowest in summer $(13.12 \%)$.

Conclusion: Vitamin D deficiency is a widely observed and preventable public health problem among children of different ages. It is necessary to increase the awareness among health professionals, and providing 25(OH)D supplements will yield generations with healthy bone structure and well growth.
\end{abstract}

Keywords: 25(OH) vitamin D, vitamin D deficiency, vitamin D insufficiency, primary school children, vitamin D levels

\section{Introduction}

25-OH vitamin D $[25(\mathrm{OH}) \mathrm{D}]$ started to gain importance worlwide for its important role in healthy bone structure and calcium and phosphate metabolism. There are many studies showing $25(\mathrm{OH}) \mathrm{D}$ deficiency and insufficiency in children worldwide (1). In the presence of $25(\mathrm{OH}) \mathrm{D}$ deficiency and insufficiency, absorbtion of both calcium and phosphorus is impaired resulting in reduced bone mineral density (2).

Low levels of 25(OH)D affects an individual's present and future health status, triggering multiple systemic responses reducing bone density and the level of immune response since there are $25(\mathrm{OH}) \mathrm{D}$ receptors in a wide range of tissues, and are related with retarded growth, skeletal deformities and secondary hyperthyroidism in the childhood, whereas
Address for Correspondence: F. Sinem Hocaoğlu-Emre, Beykent University School of Health Sciences, Department of Nutrition and Dietetics, İstanbul, Turkey

Phone: + 905065030680 E-mail: sinemhocaoglu@yahoo.com ORCID ID: orcid.org/0000-0003-2557-7378

${ }^{\circ}$ Copyright 2019 by Turkish Pediatric Endocrinology and Diabetes Society

The Journal of Clinical Research in Pediatric Endocrinology published by Galenos Publishing House.
Conflict of interest: None declared Received: 16.11 .2018 Accepted: 25.12.2018 
hip fracture in the elderly is observed in individuals with impaired bone structure $(3,4,5)$. Also, there are increasing data explaining the relationship between low levels of $25(\mathrm{OH}) \mathrm{D}$ and different types of non-skeletal diseases including some types of cancer, autoimmune, infectious, cardiovascular and psychiatric diseases (6).

Risk factors for 25(OH)D deficiency in children were defined as obesity, intestinal malabsorbtion syndromes, usage of anticonvulsant agents such as Phenytoin, phenobarbital, and carbamazepine, low levels of sun exposure, clothing habits, climatization and seasonality, nutritional choices, dark skin color (5).

In order to determine an individual's vitamin D status, serum $25(\mathrm{OH}) \mathrm{D}$ level is measured. There are different threshold points used to determine $25(\mathrm{OH}) \mathrm{D}$ status of individuals as suggested by different organizations and in guidelines $(7,8)$. Regular measurement of $25(\mathrm{OH}) \mathrm{D}$ levels in the childhood and replace the low levels with vitamin $\mathrm{D}$ fortification or supplementation is essential and a public health matter in order to acquire healthy generations with robust bone structure.

The aim of our study was to assess serum 25(OH)D levels in elementary school children aged between 6-9 years old within a year duration and determine $25(\mathrm{OH}) \mathrm{D}$ status between different seasons.

\section{Methods}

\section{Study Population and Analysis}

This is a retrospective study, conducted in one of the largest training hospitals in İstanbul, Turkey. Between September 2017-August 2018, children aged between 6-9 years old who underwent annual check-up for vitamin D status were randomly selected according to the block randomization method in order to create sampling groups of equal sample sizes from hospital information system. All of the participants in our study resided in a large metropolitan area. All were Caucasian and of Turkish origin. Health status of children were controlled from their medical data and children who have a chronic disease, eg. diabetes, inflammatory bowel disease, obesity were excluded. Additionally, children with extremely high and toxic levels of $25(\mathrm{OH}) \mathrm{D}$ were excluded, assuming the use of vitamin D supplementation. Of these children fitting to our inclusion criteria, 160 children (80 female, 80 male) were randomly selected from the hospital records for each age group in terms of their sampling and analysis date. One hundred sixty children from each age group were then divided into subgroups of 40 subjects (20 female, 20 male) for each seasons. Seasons in our climate zone are as follows: Fall (September to November), Winter
(December to February), Spring (March to May) and Summer (June to August).

The study was approved by the Institutional Ethical Committee of İstanbul Training and Research Hospital (no. 2018/1499).

Serum 25(OH)D levels were measured with chemiluminescence method using Access $25(\mathrm{OH})$ vitamin $\mathrm{D}$ total test (Beckmann Coulter, Inc., USA). Inter-assay and intra-assay $\mathrm{CV} \%$ as supplied by the manufacturer were between $5.1-8.1 \%$ and $2.2-4.7 \%$, respectively. The analysis laboratory was a participant of the RIQAS Immunoassay Speciality-1 External Quality Assurance program (Randox Laboratories Ltd., United Kingdom) for 25(OH)D and no deviation in the internal and external quality control results were observed within the study duration.

\section{Determination of Vitamin D Status}

Different classification algorithms were recruited for the determination of vitamin D status in the literature, so far. In our study, we used the widely used cut-off points as suggested by Munns et al (8). According to their criteria, vitamin D deficiency was defined as a serum $25(\mathrm{OH}) \mathrm{D}$ level of $<12 \mathrm{ng} / \mathrm{mL}$ ( $<30 \mathrm{nmol} / \mathrm{L}$ ) and insufficiency as a $25(\mathrm{OH})$ D level between 12 and $20 \mathrm{ng} / \mathrm{mL}$ (30-50 nmol/L). 25(OH) D levels higher than $20 \mathrm{ng} / \mathrm{mL}$ (50 nmol/L) was accepted as adequate.

\section{Statistical Analysis}

Data are expressed as mean \pm standard deviation. In the tables, the lowest and highest values were defined as well as the medians. The rate of deficiency, insufficiency and adequacy were shown as the number and percentage of the cases within eacy subgroup. Statistical analyses were done using the SPSS for windows (SPSS Inc, Chicago, IL). Comparisons of means between two groups were done using Student's t-tests. The ratios of vitamin D deficiency between groups were compared using the $\chi^{2}$ test. The results were evaluated using a significance value of $p<0.05$.

\section{Results}

Table 1 presents the mean serum 25(OH)D concentrations among different age groups of the study population. According to these measurements, we could not find a statistically significant difference between different genders of children in same age groups. When all age groups were compared in terms of gender, and independent of the seasonality, we could not find a difference between boys and girls. When all 640 children were evaluated together, serum 25(OH)D levels ranged from 3.90 to $64.60 \mathrm{ng} / \mathrm{mL}$; 
the median value was $25.95 \mathrm{ng} / \mathrm{mL}$. Division of children into subgroups in terms of age, gender, and seasonality did not yield a statistically significant difference between boys and girls of the same group (Table 2).

Mean 25(OH)D levels of all subjects were found to be $32.11 \pm 11.24$ in fall, $24.24 \pm 7.95$ in winter, $25.18 \pm 10.09$ in spring and $29.69 \pm 11.53$ in summer seasons. When mean levels of 25(OH)D were compared between seasons, levels measured in winter and spring were significantly lower than the levels in summer and fall $(\mathrm{p}<0.001)$ (Figure 1).

Analysis of the vitamin D status in terms of age and gender was shown in Table 3. Of all the 640 primary school children, $485(75.78 \%)$ had adequate levels of $25(\mathrm{OH})$ D. Vitamin D deficiency was observed in 36 of children

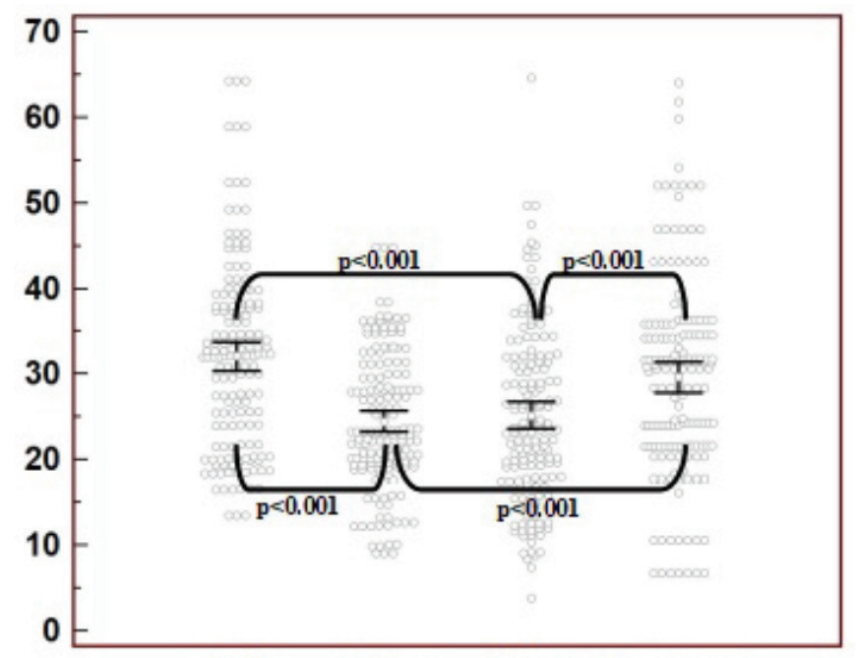

Fall Winter Spring Summer

Figure 1. Distribution of 25(OH)D in different seasons. The $y$ axis represents the $25(\mathrm{OH}) \mathrm{D}$ levels and their seasonal distribution. Significant differences were depicted with conjuncted lines between the seasons using $p$ values
$(5.62 \%)$, whereas insufficient levels of $25(\mathrm{OH}) \mathrm{D}$ were detected in 119 children (18.60\%). According to our data, the highest rates of deficiency and insufficiency were found in the 8-year old children's group $(8.12 \% ; 21.25 \%$, respectively). Furthermore, when the children were divided into subgroups in terms of age and gender, we detected a statistically significant difference between 6-year old girls and boys for the rate of deficiency, and 7-year old girls and boys for the rate of insufficiency (Table 3).

The rate of vitamin D insufficiency and deficiency together was highest in spring, and lowest in summer season $(13.12 \%)$ (Table 4). Comparison of insufficiency and deficiency rates between the seasons fall-winter, wintersummer, spring-summer, fall-spring yielded statistical significance (Figure 2).

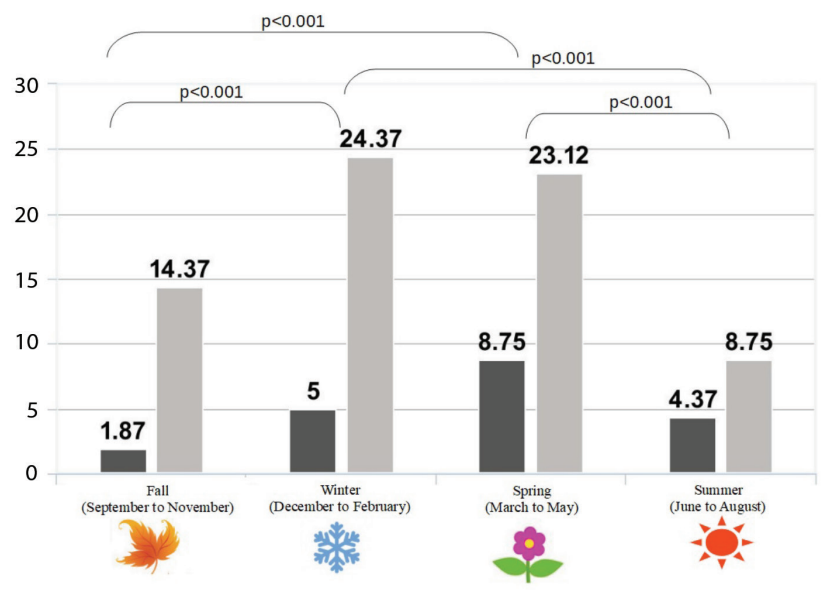

Figure 2. Rate of vitamin D deficiency and insufficiency by season. 25(OH)D $<20 \mathrm{ng} / \mathrm{mL}$ accepted as deficiency (black color); 25(OH)D between 21-29 ng/mL accepted as insufficiency (grey color). Significant differences were depicted with conjuncted lines between the seasons using $p$ values

Table 1. 25(OH)D levels of children for different age groups

\begin{tabular}{|c|c|c|c|c|}
\hline \multirow[t]{2}{*}{ Age (years); number per group } & \multicolumn{4}{|c|}{$\begin{array}{l}\text { Serum } 25(\mathrm{OH}) \mathrm{D} \text { levels }(\mathrm{ng} / \mathrm{mL}) \\
\text { Mean } \pm \text { SD (lowest value-highest value; median) }\end{array}$} \\
\hline & Girls & Boys & $\mathrm{p}$ & Total \\
\hline $\begin{array}{l}7 \\
(\text { Girls } n=20 ; \text { Boys } n=20 ; \text { Total } n=40)\end{array}$ & $\begin{array}{l}25.43 \pm 11.22 \\
(10.40-64.60 ; 21.70)\end{array}$ & $\begin{array}{l}28.27 \pm 8.57 \\
(9.1-46.5 ; 29.2)\end{array}$ & 0.29 & $\begin{array}{l}26.61 \pm 10.22 \\
(9.10-64.60 ; 24.90)\end{array}$ \\
\hline $\begin{array}{l}9 \\
(\text { Girls } n=20 ; \text { Boys } n=20 ; \text { Total } n=40 \text { ) }\end{array}$ & $\begin{array}{l}27.20 \pm 9.87 \\
(8.90-45.10 ; 30.20)\end{array}$ & $\begin{array}{l}28.57 \pm 10.75 \\
(1230-52.10 ; 25.85)\end{array}$ & 0.63 & $\begin{array}{l}27.84 \pm 10.21 \\
(8.90-52.10 ; 28.20)\end{array}$ \\
\hline $\begin{array}{l}\text { Overall } \\
(\text { Girls } n=80 ; \text { Boys } n=80 ; \text { Total } n=160 \text { ) }\end{array}$ & $\begin{array}{l}26.83 \pm 10.65 \\
(6.70-64.60 ; 25.15)\end{array}$ & $\begin{array}{l}28.08 \pm 11.63 \\
(3.90-64.30 ; 28.20)\end{array}$ & 0.36 & $\begin{array}{l}27.51 \pm 11.23 \\
(3.90-64.60 ; 25.95)\end{array}$ \\
\hline
\end{tabular}




\begin{tabular}{|c|c|c|c|c|}
\hline \multirow{2}{*}{ Age (years); number per group } & \multicolumn{4}{|c|}{$\begin{array}{l}\text { Fall-Serum } 25(\mathrm{OH}) \mathrm{D} \text { levels }(\mathrm{ng} / \mathrm{mL}) \\
\text { Mean } \pm \mathrm{SD} \text { (lowest value-highest value; median) }\end{array}$} \\
\hline & Girls & Boys & $\mathrm{p}$ & Total \\
\hline $\begin{array}{l}6 \\
(\text { Girls } n=20 ; \text { Boys } n=20 ; \text { Total } n=40 \text { ) }\end{array}$ & $\begin{array}{l}31.36 \pm 7.76 \\
(20.00-38.00 ; 34.60)\end{array}$ & $\begin{array}{l}38.07 \pm 20.76 \\
(13.5-64.3 ; 37.25)\end{array}$ & 0.52 & $\begin{array}{l}34.34 \pm 14.29 \\
(13.5-64.3 ; 36.80)\end{array}$ \\
\hline $\begin{array}{l}7 \\
(\text { Girls } n=20 ; \text { Boys } n=20 ; \text { Total } n=40)\end{array}$ & $\begin{array}{l}25.16 \pm 11.00 \\
(16.5-39.4 ; 18.5)\end{array}$ & $\begin{array}{l}40.30 \pm 5.48 \\
(36.1-46.5 ; 38.30)\end{array}$ & 0.072 & $\begin{array}{l}34.34 \pm 14.29 \\
(16.5-46.5 ; 35.4)\end{array}$ \\
\hline $\begin{array}{l}9 \\
(\text { Girls } n=20 ; \text { Boys } n=20 ; \text { Total } n=40 \text { ) }\end{array}$ & $\begin{array}{l}31.61 \pm 5.93 \\
(21.5-39.8 ; 32.55)\end{array}$ & $\begin{array}{l}31.15 \pm 9.58 \\
(19.9-49.3 ; 32.10)\end{array}$ & 0.91 & $\begin{array}{l}31.34 \pm 8.06 \\
(19.9-49.3 ; 32.40)\end{array}$ \\
\hline $\begin{array}{l}\text { Overall } \\
\text { (Girls } n=80 \text {; Boys } n=80 \text {; Total } n=160 \text { ) }\end{array}$ & $\begin{array}{l}30.7 \pm 10.76 \\
(16.5-58.9 ; 30.90)\end{array}$ & $\begin{array}{l}33.77 \pm 11.80 \\
(13.5-64.3 ; 34.00)\end{array}$ & 0.34 & $\begin{array}{l}32.11 \pm 11.24 \\
(13.5-64.3 ; 32.30)\end{array}$ \\
\hline
\end{tabular}

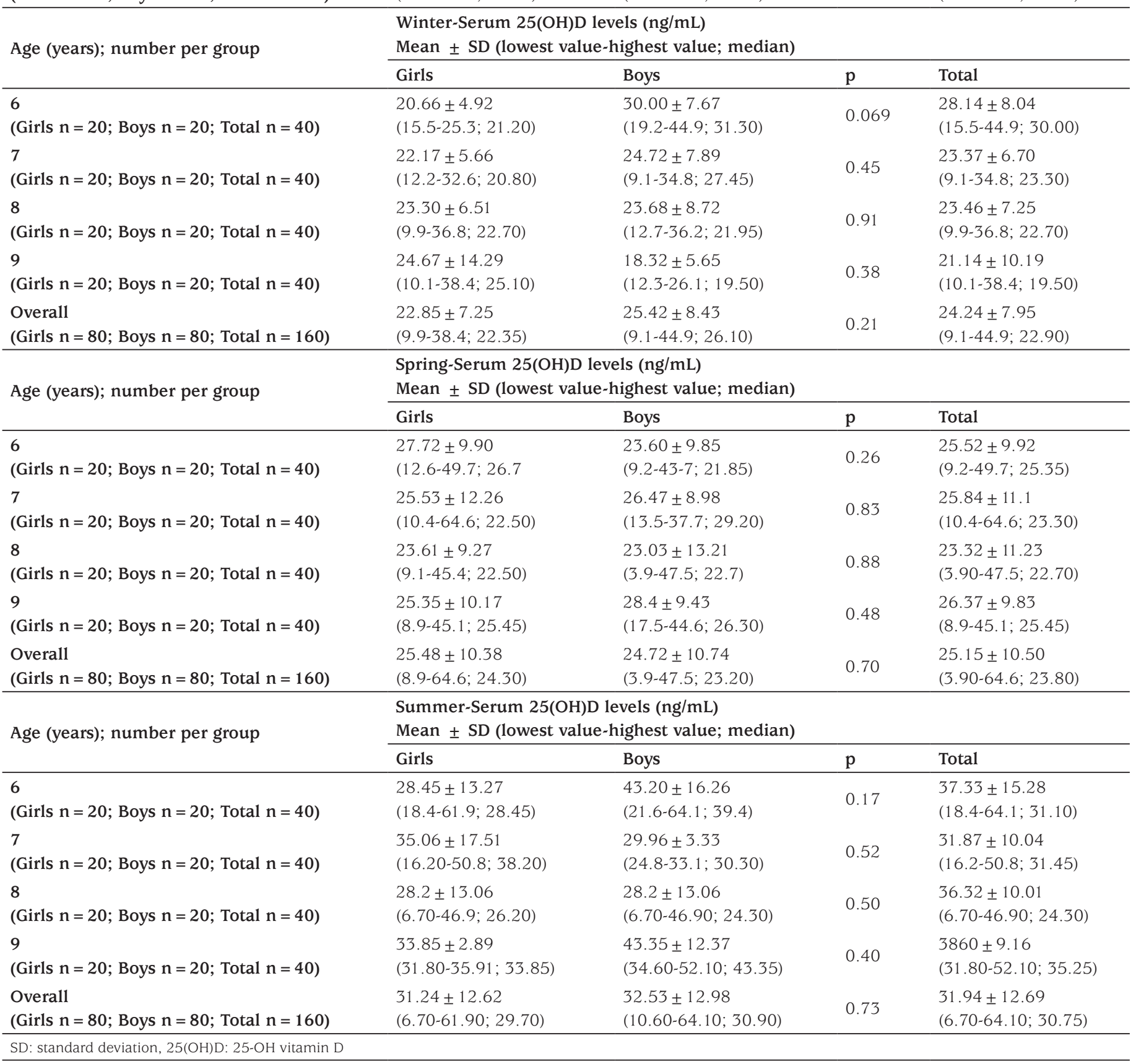




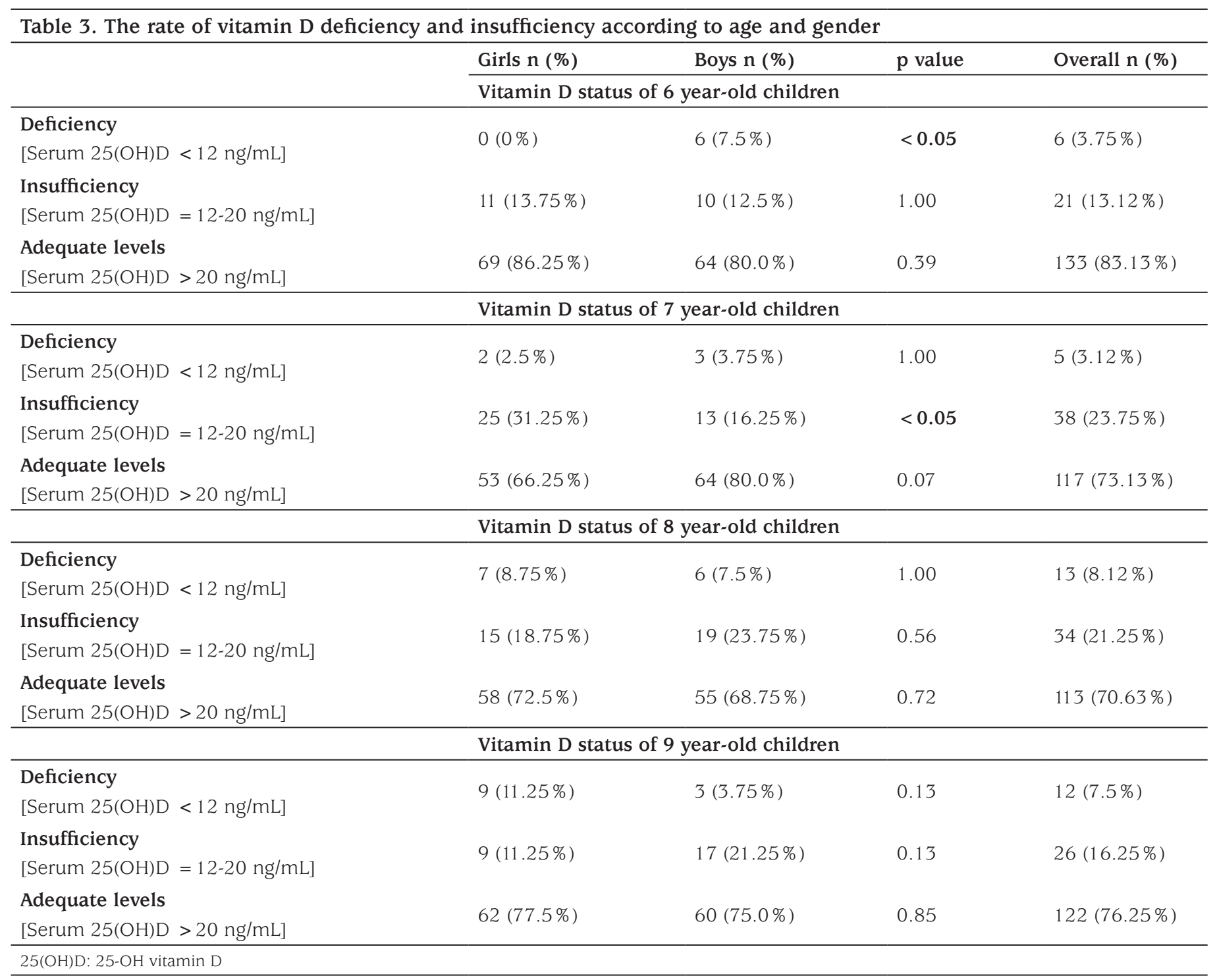

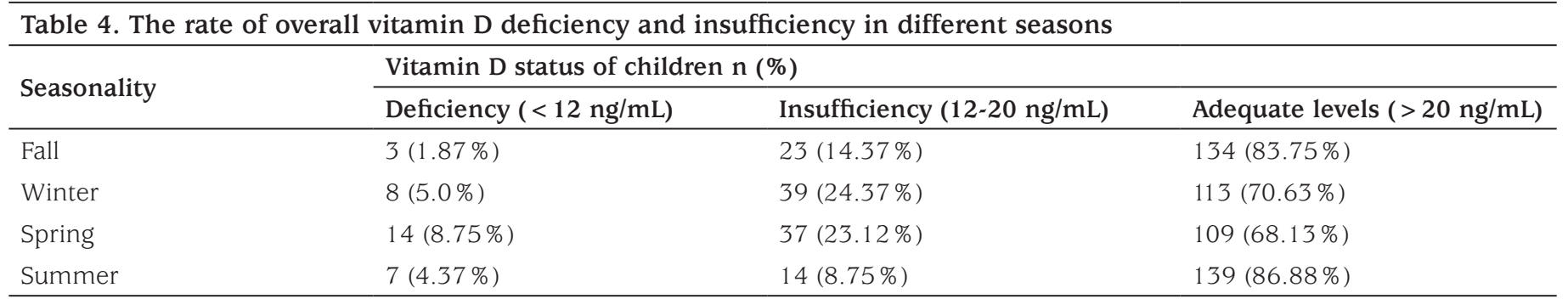

\section{Discussion}

Our study includes Turkish elementary school children of both genders between 6-9 years old, residing in the largest metropol of Turkey, and one of the largest metropols of Europe, İstanbul. The subjects were chosen among the healthy children, who underwent laboratory tests for their routine annual check-up.
There are different suggested cut-off points for evaluation of vitamin D status. The Endocrine Society accepts a threshold of $12-20 \mathrm{ng} / \mathrm{mL}$ for insufficiency, and $>20 \mathrm{ng} / \mathrm{mL}$ to represent sufficiency (8). However, the Institutes of Medicine claims that $25(\mathrm{OH}) \mathrm{D}$ levels above $20 \mathrm{ng} / \mathrm{mL}$ does not supply an additional benefit for bone health (7). Based on these approaches, the prevalence of insufficient and deficient individuals highly vary between the studies worldwide. In 
our study, we used the cut-off points determined by the Endocrine Society, since that classification would be most appropriate for our group.

Our study demonstrated that, taken together, a total of 155 children out of 640 (24.21\%) had deficient and insufficient levels of $25(\mathrm{OH}) \mathrm{D}$ in their blood serum. We also found that, the 25(OH)D levels were significantly differed depending on the seasonality. The rate of deficient and insufficient levels of 25(OH)D were higher in the winter and spring, when compared to other seasons. Additionally, while we compared the number of children with inadequate levels of $25(\mathrm{OH}) \mathrm{D}$, we found that $78(12.18 \%)$ of were girls, whereas $77(12.03 \%)$ of were boys.

This is the first and wide analysis of vitamin D status among primary school age group of children in Turkey. There is a range of studies showing deficient or inadequate levels of $25(\mathrm{OH}) \mathrm{D}$ in children, worldwide. The findings of our study have similar and different findings with other studies of Turkish and European origin.

In their study with Turkish children of 11-18 ages, Karagüzel et al (9) used the cut-off value $20 \mathrm{ng} / \mathrm{mL}$ for deficiency, and found the prevalence of vitamin D deficiency $93 \%$ during spring and $71 \%$ during autumn seasons, with an overall prevalence of $82 \%$. While we used cut-off point $12 \mathrm{ng} /$ $\mathrm{mL}$ for deficiency in our study group, we found vitamin $\mathrm{D}$ deficiency was $8.75 \%$ during spring, and $1.87 \%$ during autumn. Additionally, insufficient levels of vitamin D were detected in the spring and autumn seasons, with a rate of $23.12 \%$ and $14.37 \%$, respectively. The difference between their study and ours might be due to the following reasons: Firstly, their study group consisted of a different age group than our group, who are teenagers, among which are girls wearing traditional clothing covering their body as a result of regional beliefs. Secondly, their study was conducted in the northeastern part of Turkey with a colder and less sunny seasonal times when compared to İstanbul (10). Lastly, their cut-off points are higher than the values we recruited for the classification of our subjects.

Erol et al (11) also measured the 25(OH)D levels of 280 children aged 3-17 years old, living in İstanbul, Turkey, the same region our study group is located. They used the classification suggested by American Pediatric Endocrine Association defining a serum 25(OH)D level less than 15 $\mathrm{ng} / \mathrm{mL}$ as deficiency, and levels between 15 and $20 \mathrm{ng} / \mathrm{mL}$ as insufficiency. Of the individuals, they found $80.36 \%$ rate of deficiency and $11.79 \%$ rate of insufficiency in the end of winter samples.

In a study from Kuwait, recruiting the similar age group subjects, the defined that being $\leq 8.5$ years old is a significant risk factor for vitamin D deficiency (12). This finding is consistent with our data showing higher rate of deficiency and insufficiency in 8 years old children. The similarity between two studies might be a result of accelerated growth in children of this age.

In their study analyzing vitamin D status' of a large group of Greek children between 9-13 years old, and using the same cut-off points with our study, Manios et al found that the overall prevalence of vitamin $\mathrm{D}$ deficiency and insufficiency were $5.2 \%$ and $52.5 \%$, respectively (13). The lower rate of vitamin D deficient children in our study group might be a result of their sampled age group and this group's increased demand to $25(\mathrm{OH}) \mathrm{D}$ as a result of accelerated growth. Additionally, they did not include the samples on the summer season, since they collected samples from schools, and the schools were on summer break from June to September. They also observed a higher prevalence of low 25(OH)D levels in girls, when compared to boys. Female gender is a well-known reason of both vitamin D deficiency and insufficiency, and data discussing this issue suggested different reasons. Traditional clothing as a result of religional beliefs is one of the arguments that is put forward (14). However, 25(OH)D levels were still found to be lower in girls residing in countries that traditional clothing is not widely used $(13,15,16)$. Studies collecting dietary $25(\mathrm{OH}) \mathrm{D}$ intake of children revealed that mean intake of $25(\mathrm{OH}) \mathrm{D}$ with food consumption is lower in girls when compared to boys of same age (17). Additionally, tendency to outdoor activities and time spent under direct sunlight is lower in girls $(9,11)$. Recently, female sex hormones (mainly estradiol and estrogens) were shown to be affecting the $25(\mathrm{OH}) \mathrm{D}$ levels in females altering the synhesis and metabolism (18).

With the increased level of knowledge and awareness on vitamin $\mathrm{D}$ and its relation to growth and disease susceptibility, 25(OH)D fortified foods were started to be sold in public markets in some countries (19). In Turkey, $25(\mathrm{OH}) \mathrm{D}$ fortified foods are not common in markets and their prices are higher when compared to the similar group of foods. Thus, for the individuals with low income, vitamin D synthesis through proper and adequate sun exposure remains the sole choice. It has been suggested that sunlight exposure of dorsal body areas for 15 minutes at least three times a week is sufficient to maintain adequate levels of $25(\mathrm{OH}) \mathrm{D}$ for adults. In case of diminished or decreased sun exposure due to different reasons including low level of outdoor activities, clothing habits, climate changes, $25(\mathrm{OH})$ $\mathrm{D}$ supplementation is required if the consumed amount of $25(\mathrm{OH}) \mathrm{D}$ with foods is not sufficient (1). There are data presenting higher mean blood $25(\mathrm{OH}) \mathrm{D}$ levels and lower 
prevalence of insufficiency and deficiency in children from colder regions of world, suggesting that the higher rate of consumption of fish oil and fish types living in cold sea habitats helped those children to maintain the blood 25(OH) D levels within adequate limits, despite their less exposure to sunlight when compared to the children of warm regions $(20,21)$.

A five-year nationwide 'vitamin D prophylaxis augmentation programme' was initiated in 2005 with a collaboration between Turkish Pediatric Endocrine Society and Ministry of Health of Turkey, recruiting free distribution of vitamin D drops to all 0-12 months old children. Consequently, these efforts resulted in a decline in the prevalence of rickets from $6 \%$ in 1998 to $0.1 \%$ in 2008 in children under 3 years of age (22). However, our study and other forementioned studies reveal the need for vitamin $\mathrm{D}$ supplementation for children of different age groups. Although vitamin D supplements are sold for very low prices, and the drop, powder, ampoule forms are covered by government insurance and can be obtained free, there is still need for public awareness in order to provide adequate levels of $25(\mathrm{OH}) \mathrm{D}$ for children. Since the administration of supplements to children is under the control of their parents, parent integration is highly essential even though medical and legal authorities provide the sufficient support.

\section{Study Limitations}

Our study has several limitations. Since we used a retrospective data obtained from hospital records of our study group, there is lack of data regarding BMI, social status, time spent under daylight, parathormone levels, dressing habits and daily 25(OH)D intake of children. Additionally, this is a one center study held in İstanbul, thus it does not reflect the status of all Turkish children.

One of the strengths of our study is that it is distinctive for comprising large number of healthy elementary school children aged between 6-9 years and grouping them according to gender and age.

\section{Conclusion}

Our findings reveal that vitamin D deficiency and insufficiency is a common condition on winter and spring times, among children of elementary school age. 25(OH) D supplementation and close follow-up of vitamin D status especially in the winter and post-winter period are required to supply a strong bone structure and healthy growth. Children with adequate levels of $25(\mathrm{OH}) \mathrm{D}$ and healthy skeleton will benefit in their adult years, thus this is a public health issue, and should be taken into consideration by authorities using the recommendations from appropriate guidelines.

\section{Ethics}

Ethics Committee Approval: The study was approved by the Institutional Ethical Committee of İstanbul Training and Research Hospital (no. 2018/1499).

Informed Consent: Consent form was filled out by all participants.

Peer-review: Externally and internally peer-reviewed.

\section{Authorship Contributions}

Concept: Devrim Sarıbal, Design: Devrim Sarıbal, Data Collection or Processing: F. Sinem Hocaoğlu-Emre, Osman Oğuz, Analysis or Interpretation: Devrim Sarıbal, Osman Oğuz, Literature Search: Devrim Sarıbal, Osman Oğuz, Writing: F. Sinem Hocaoğlu-Emre.

Financial Disclosure: The authors declared that this study received no financial support.

\section{References}

1. Cediel G, Pacheco-Acosta J, CastiUo-Durdn C. Vitamin D deficiency in pediatric clinical practice. Arch Argent Pediatr 2018;116:75-81.

2. Heaney RP. Functional indices of vitamin D status and ramifications of vitamin D deficiency. Am J Clin Nutr 2004;80(Suppl 6):17061709 .

3. Adams JS, Hewison M. Update in vitamin D. J Clin Endocrinol Metab 2010;95:471-478.

4. DeLuca HF. Overview of general physiologic features and functions of vitamin D. Am J Clin Nutr 2004;80(Suppl 6):1689-1696.

5. Holick MF. Vitamin D Deficiency. N Engl J Med 2007;357:266-281.

6. Autier P, Boniol M, Pizot C, Mullie P. Vitamin D status and ill health: a systematic review. Lancet Diabetes Endocrinol 2014;2:76-89. Epub 2013 Dec 6

7. Rosen CJ, Abrams SA, Aloia JF, Brannon PM, Clinton SK, Durazo-Arvizu RA, Gallagher JC, Gallo RL, Jones G, Kovacs CS, Manson JE, Mayne ST, Ross AC, Shapses SA, Taylor CL. IOM committee members respond to Endocrine Society vitamin D guideline. J Clin Endocrinol Metab 2012;97:1146-1152. Epub 2012 Mar 22

8. Munns CF, Shaw N, Kiely M, Specker BL, Thacher TD, Ozono K, Michigami T, Tiosano D, Mughal MZ, Mäkitie O, Ramos-Abad L, Ward L, DiMeglio LA, Atapattu N, Cassinelli H, Braegger C, Pettifor JM, Seth A, Idris HW, Bhatia V, Fu J, Goldberg G, Sävendahl L, Khadgawat R, Pludowski P, Maddock J, Hyppönen E, Oduwole A, Frew E, Aguiar M, Tulchinsky T, Butler G, Högler W. Global Consensus Recommendations on Prevention and Management of Nutritional Rickets. J Clin Endocrinol Metab 2016;101:394-415. Epub 2016 Jan 8

9. Karagüzel G, Dilber B, Çan G, Ökten A, Değer O, Holick MF. Seasonal Vitamin D Status of Healthy Schoolchildren and Predictors of Low Vitamin D Status. J Pediatr Gastroenterol Nutr 2014;58:654-660.

10. Meteorology data. Last accessed date: 12 November 2018. Available at: https://www.mgm.gov.tr/veridegerlendirme/il-ve-ilceler-istatistik. aspx?m = ISTANBUL 
11. Erol M, Yiğit Ö, Küçük SH, Gayret Ö. Vitamin D Deficiency in Children and Adolescents in Bağcılar, İstanbul. J Clin Res Pediatr Endocrinol 2015;7:134-139.

12. Alyahya KO. Vitamin D levels in schoolchildren: a crosssectional study in Kuwait. BMC Pediatr 2017;17:213.

13. Manios Y, Moschonis G, Hulshof T, Bourhis AS, Hull GLJ, Dowling KG, Kiely ME, Cashman KD. Prevalence of vitamin D deficiency and insufficiency among schoolchildren in Greece: the role of sex, degree of urbanisation and seasonality. Br J Nutr 2017;118:550-558. Epub 2017 Oct 2

14. Hatun S, Islam O, Cizmecioglu F, Kara B, Babaoglu K, Berk F, Gökalp AS. Subclinical vitamin D deficiency is increased in adolescent girls who wear concealing clothing. J Nutr 2005;135:218-222.

15. Mansbach JM, Ginde AA, Camargo CA Jr. Serum 25-Hydroxyvitamin D Levels Among US Children Aged 1 to 11 Years: Do Children Need More Vitamin D? Pediatrics 2009;124:1404-1410.

16. Roh YE, Kim BR, Choi WB, Kim YM, Cho MJ, Kim HY, Park KH, Kim KH, Chun P, Kim SY, Kwak MJ. Vitamin D deficiency in children aged 6 to
12 years: single center's experience in Busan. Ann Pediatr Endocrinol Metab 2016;21:149-154. Epub 2016 Sep 30

17. Moore C, Murphy MM, Keast DR, Holick MF. Vitamin D intake in the United States. J Am Diet Assoc 2004;104:980-983.

18. Crescioli C, Minisola S. Vitamin D: autoimmunity and gender. Curr Med Chem 2017:24:2671-2686.

19. Holick MF. High Prevalence of Vitamin D Inadequacy and Implications for Health Mayo Clin Proc 2006;81:353-373.

20. Wahl DA, Cooper C, Ebeling PR, Eggersdorfer M, Hilger J, Hoffmann K, Josse R, Kanis JA, Mithal A, Pierroz DD, Stenmark J, Stöcklin E, Dawson-Hughes B. A global representation of vitamin D status in healthy populations. Arch Osteoporos 2012;7:155-172.

21. Pedersen JI. Vitamin D requirement and setting recommendation levels-current Nordic view. Nutr Rev 2008;66(10 Suppl 2):165-169.

22. Hatun Ş, Ozkan B, Bereket A. Vitamin D deficiency and prevention: Turkish experience. Acta Paediatr 2011;100:1195-1199. Epub 2011 Jul 4 